\title{
A IMPORTÂNCIA DA ODONTOLOGIA PARA A SAÚDE DA POPULAÇÃO
}

\author{
Maria Eliza Jardim Rodrigues \\ Graduada em Odontologia - Especialista em Endodontia - \\ Especialista em Implantodontia \\ Clínica Geral em consultório particular \\ $\triangle$ mejardim@gmail.com
}

\section{BREVE HISTÓRICO DA ODONTOLOGIA}

No passado, não existia o curso de graduação para a profissão odontológica. A figura típica do dentista até mais ou menos 1700, era “Tiradentes”, que trabalhava em praça pública e, seu trabalho era a remoção de dentes em cadeiras que também eram utilizadas pelos barbeiros.

A partir de 1800, com a existência de cadeiras apropriadas, alguns trabalhos odontológicos como prótese e tratamento de canal começaram a ser realizados. Com a descoberta da anestesia local em 1884 por Horace Wells, a odontologia ganhou objetivos curativos e reparadores e, finalmente, lhe foi atribuída a função preventiva, que até hoje é o conceito compatível com uma odontologia de padrão elevado, seja de caráter público ou privado.

\section{ODONTOLOGIA ATUAL}

O nível da odontologia atual é do mais alto gabarito, possibilitando grandes reabilitações com excelente estética dentro do conceito reparador/curativo. O Brasil ocupa uma posição de destaque no cenário da odontologia mundial, exportando profissionais para outros países, dada a capacidade e treinamento adquiridos nos cursos de graduação e pósgraduação em odontologia existentes no país.

\section{MEU OLHAR PROFISSIONAL}

A minha visão da odontologia é ampla, já que trabalho há 33 anos na profissão com uma clínica atuante e, sempre voltada para o bem estar do paciente. Acho que é preciso olhar 
a odontologia como uma vertente da saúde geral do paciente, já que a cavidade oral, lugar de atuação do profissional de odontologia, faz parte do corpo humano, e como tal, precisa estar saudável, para que a saúde do indivíduo esteja em harmonia. Outra função importante, do profissional de saúde bucal, está no fato, deste profissional ter condições de detectar doenças ligadas ao corpo através de exames realizados na boca, uma vez que trabalhamos diretamente com a porta de entrada de muitas doenças e ainda, muitas têm manifestação oral antes de qualquer outra parte do organismo.

Antigamente, havia pacientes de todas as idades necessitando de vários tipos de tratamento odontológico. Hoje, devido às ações preventivas e maior esclarecimento da população, assim como o envelhecimento desta, a faixa etária predominante para tratamento dentário curativo está na terceira idade. Os procedimentos praticados nos jovens e crianças estão voltados, principalmente, para prevenção e estética.

Infelizmente, o tratamento dentário ainda é objeto de luxo para a população em geral devido ao alto custo do tratamento em clínica privada e à falta de uma odontologia pública eficiente. Hoje, assim como na medicina, existem convênios odontológicos, que estão se inserindo no mercado ocupando o espaço entre paciente e dentista fazendo com que os tratamentos sejam precários em função do elevado número de conveniados e a baixa remuneração ao profissional, paga por estes convênios odontológicos.

Mesmo com todo este cenário, a odontologia ainda me fascina. Procuro me atualizar sempre, pois este é o caminho para me manter atuante. Estou realizada profissionalmente, pois penso que cumpri e, ainda cumpro com o meu dever de profissional de saúde promovendo o bem estar do paciente dentro do meu campo profissional.

\section{FONTES CONSULTADAS}

ODONTOLOGIA EM FOCO. Brasília: Conselho Federal de Odontologia, 5a ed., 2015. Disponível em: <http://cfo.org.br/wp-content/uploads/2015/07/revista5.pdf >. Acesso em: 14 set. 2015.

WIKIPÉDIA. História da odontologia.

Disponível em: <https://pt.wikipedia.org/wiki/História_da_odontologia>. Acesso em: 14 set. 2015. 